\title{
Incidence and population builds up of $P$. lotus infesting Capsicum chinense Jacq. in relation to weather factors
}

\author{
M. BATHARI ${ }^{1}$, S. RAHMAN ${ }^{1}$ AND D. SHARMAH* \\ Krishi Vigyan Kendra, SOUTH TRIPURA (TRIPURA) INDIA \\ ${ }^{1}$ Department of Entomology, Assam Agricultural University, JORHAT (ASSAM) INDIA
}

\section{ARITCLE INFO}

Received : 17.08 .2016

Revised : 10.09 .2016

Accepted : 24.09 .2016

\section{KEY WORDS :}

Capsicum chinense, Yellow mite, Population, Weather parameters, Correlation

*Corresponding author:

Email : dasharmah@gmail.com

\begin{abstract}
An Experiment was conducted in the experimental plot, Department of Entomology, Assam Agricultural University, Jorhat during 2014 and 2015 to study the population build up of P. lotus infesting Capsicum chinense with respect to weather factors. In the present investigation, the highest population (no/leaf) of yellow mite, P. latus was observed in the month of March with maximum 45 and 28 number of yellow mite per leaf in 2014 and 2015, respectively. The highest overall per cent incidence recorded was 80.61 in the last week of March whereas lowest overall incidence was found in May with 20.12 per cent mite incidence The correlation studies between P. latus and weather parameters revealed that population build up of $P$. latus found to be significant negative correlation with morning relative humidity ( $\mathrm{r}=-0.787$ and $\mathrm{r}=-721)$ and rainfall $(\mathrm{r}=-0.526)$ in both the years, respectively. Maximum temperature, minimum temperature and evening relative humidity showed a negative and non- significant correlation with mite population. Bright sunshine hour was found to be positively correlated. This present findings will certainly be a helpful for yellow mite forecasting as well as management point of view and to have profitable cultivation of Capsicum chinense by way of mite free crop production.
\end{abstract}

How to view point the article : Bathari, M., Rahman, S. and Sharmah, D. (2016). Incidence and population builds up of $P$. lotus infesting Capsicum chinense Jacq. in relation to weather factors. Internat. J. Plant Protec., 9(2) : 578-582, DOI : 10.15740/HAS/IJPP/9.2/578-582. 